Литвиненко Світлана

доктор педагогічних наук, професор, професор кафедри практичної психології і психотерапії

ORCID iD: 0000-0002-7736-2152

Ямницький Вадим

доктор психологічних наук, професор, професор кафедри практичної психології і психотерапії Рівненського державного гуманітарного університету

ORCID iD: 0000-0002-1741-1303

DOI https://doi.org/10.35619/prap_rv.vi13.125

\title{
ПСИХОЛОГІЧНІ ОСОБЛИВОСТІ РОБОТИ З БАТЬКАМИ В ПСИХОТЕРАПІЇ ДІТЕЙ ТА ПІДЛІТКІВ
}

Анотація. У статті здійснено обтрунтування особливостей психотерапії з дітьми та підлітками, оскільки такий напрям психологічної допомоги відрізняється від психотерапї з дорослими більш складною структурою психотерапевтичної ситуації, що зумовлює й більш складну систему відносин в иій ситуації. Передусім діти і підлітки, як пацієнти психотерапії, характеризуються залежністю від батьків та впливу на них найближчого оточення, а тому дитячий психотерапевт в роботі формує подвійні терапевтичні відносини та робочий альянс.

У роботі з батьками психолог звертається до розуміння особливостей та оцінки можливостей залучення батьків до участі в психотерапії й визначення стилю роботи з ними. Батьки потребують емпатійної підтримки психолога в подоланні опору щодо звернення про допомогу; а також допомоги в розумінні психологічних особливостей та вікових криз у розвитку дітей та підлітків; розумінні особливостей процесу та результатів терапії. В ході терапевтичної роботи важливим є з'ясування ролі сім'ї в розвитку порушень y дитини, а також впливу проблем та порушень у розвитку дитини на ї сім'ю. Доведено, щзо при плануванні, організації $і$ проведенні психотерапевтичної роботи з дітьми та підлітками слід враховувати чинники, щьо зумовлюють опір сім'ї та батьків на початку та в ході прочесу психотерапії. Зневаження або ігнорування дитячими психотерапевтами/ психологами урахування опору сім'ї та батьків пацієнтів, може призвести до зниження ефективності терапевтичного прочесу і редукиї вже досягнутих позитивних результатів, передчасного припинення чи переривання психотерапії. Важсливю опорою в побудові терапевтичного альянсу з сім'єю є зосередження уваги на здорових та позитивних аспектах досвіду взаємодії дитини $і$ батьків як головного ресурсу для розвитку та змін у ході терапевтичного процесу.

Виявлено, щуо ситуація приналежності батьків як обов'язкового елемента дитячої психотерапї створює труднощі в пошуках компромісу в дотриманні етичних принципів професійної діяльності щзодо інформування $i$ водночас збереження конфіденційності в роботі з дітьми і підлітками.

Ключові слова: психотерапія з дітьми та підлітками, опір батьків та сім'і в психотерапї дітей та підлітків, терапевтичний контракт, терапевтичний альянс з сім'єю.

Постановка проблеми. У сучасних умовах психотерапія посідає особливе місце серед різновидів професійної допомоги дорослим, дітям і підлітками. У характеристиках дітей та підлітків як пацієнтів психотерапії дослідники (Бремс, Бріш, Лендрет, Пуйда, Четік та ін.) звертаються до таких їхніх особливостей і потреб, як-от: стан безперервного розвитку, постійні особистісні зміни та незрілість дитячого «Я»; нерівномірність розвитку афективновольових і когнітивних процесів, труднощі саморегуляції та афективна вразливість; потреби в автономії, встановленні безпечних емоційних стосунків та взаємодії з дорослим, пізнанні навколишнього та грі; залежність дитини від батьків та впливу на неї близького оточення; 
відсутність мотивації до проходження психотерапії; значущість невербальної комунікації у взаємодії та спілкуванні; наближеність до первинних процесів та несвідомого, (метафори, фантазії, ірраціональні страхи, тощо).

Згадані особливості визначають сукупність цілей дитячої та підліткової психотерапії: цілі, пов'язані з розв'язанням проблем дітей та підлітків; цілі, пов'язані з розвитком потенціалу дітей та підлітків, резервів особистісного зростання (самостійності і автономії, здатності усвідомлювати свої потреби і проблеми, формування адекватної та стійкої самооцінки; розширення досвіду дитини та повернення до нормальної траєкторії розвитку); цілі, пов'язані з генералізацією та збереженням терапевтичних змін (Бремс, 2002, с. 56). Вочевидь, зазначені цілі постають не тільки як власне психотерапевтичні, але й як розвивально-корекційні. Водночас сучасні психотерапевти (Васильєва, Лендрет, Пуйд, Циантис та ін.), які працюють 3 дітьми та підлітками, запорукою успішності досягнення цілей та забезпечення ефективності психотерапевтичного процесу уважають забезпечення співробітництва з батьками й пропрацювання дитячо-батьківських стосунків.

Аналіз останніх досліджень. Виразною особливістю, відзначеною в теорії і практиці дитячої та підліткової психотерапії різних модальностей (Фрейд, Бремс, Дольто, Екслайн, Ліфінцева, Ремшмідт, Сєрих, Четік та ін.) є залежність дитини від батьків та впливу на неї найближчого оточення, оскільки звернення про допомогу завжди ініційоване батьками чи опікунами, а не самою дитиною. Особистість дитини та іiі становлення неможливо розглядати поза контекстом і впливом сімейної системи (Боуен, Будінайте, Варга, Стерн, Федуніна та ін.). Відтак, між психотерапевтом і дитиною завжди $є$ посередники, а до структури психотерапевтичної ситуації в індивідуальній роботі 3 дитиною потенційно приналежні позиції: «дитина - терапевт - батьки». 3 цього випливає необхідність більшою мірою, ніж у психотерапії дорослих, урахування фізичної та емоційної залежності дитини від впливу сімейного та найближчого оточення.

Метою статті виступило обгрунтування психологічних особливостей роботи 3 батьками в психотерапії дітей та підлітків.

Виклад основного матеріалу дослідження. Сімейне оточення дитини виступає в ролі третьої сторони в дитячій психотерапії і має безпосередній або опосередкований вплив на ії процес і результати. Сучасні уявлення про модель відносин «батьки - дитина - терапевт» як певну систему (Боуен, Варга, Оліферович та ін.), у якій елементи перебувають у динамічних взаємозв'язках, дозволяють стверджувати, що будь-які психотерапевтичні впливи, спрямовані на зміну одного елемента, призводить до модифікації усієї системи. Відтак різні терапевтичні підходи постають як різні точки доступу до однієї і тієї ж системи.

На відміну від дорослих, діти і підлітки рідко усвідомлюють себе «людьми 3 психологічними труднощами чи проблемами», які потребують психотерапевтичної допомоги (за винятком дітей підліткового та юнацького віку). Рішення про звернення до дитячого психотерапевта або психолога виходить від батьків, які й визначають запит звернення та цілі психотерапії. Крім того, запит на психотерапію може виходити від адміністрації навчального закладу (школи або дитячого садка), лікарів (психоневролога, дитячого психіатра, педіатра тощо), соціальної служби чи органів опіки. У такому випадку до структури психотерапевтичної ситуації долучається ще одна, четверта сторона, яка перебуває поза терапевтичною ситуацією, проте має з нею зв'язок. У будь-якому випадку, запит про допомогу виходить від дорослих, які стурбовані порушенням поведінки дитини, розладами чи симптомами, способами реагування та неможливістю з ними впоратися тощо.

Відтак, психотерапія 3 дітьми відрізняється від психотерапії 3 дорослими більш складною структурою психотерапевтичної ситуації, що зумовлює й більш складну систему відносин в цій ситуації. Передусім дитячий психотерапевт в роботі з дорослими та 3 дитиною формує подвійні терапевтичні відносини та робочий альянс. Під робочим альянсом 3 батьками розуміємо свідоме об'єднання зусиль батьків і психотерапевта в терапевтичній роботі з дитиною. Водночас сім'ї та батьки відрізняються за здатністю виявляти піклування про розвиток та особистість дитини, готовністю та спроможністю співробітництва в ході проведення психотерапії. В роботі з батьками психотерапевт звертається до розуміння 
особливостей та оцінки можливостей залучення батьків до участі в психотерапії й визначення стилю роботи 3 ними. При цьому важливо враховувати не тільки стосунки батьків як подружжя, але й те, на якій стадії розвитку батьківських функцій знаходиться кожен з партнерів.

Звернемося до більш докладного розгляду особливостей формування робочого альянсу с батьками в психотерапії дітей та підлітків. Загальновідомо, що у процесі психотерапії та консультування фахівці зустрічаються з феноменом опору, що обумовлений зовнішніми причинами або внутрішніми конфліктами пацієнта/клієнта. У загальному вигляді термін опору позначає захисні зусилля індивіда/індивідів (переважно несвідомі), спрямовані на уникнення поглибленого самопізнання. Опір може виникати на різних етапах психотерапевтичного процесу та виявлятися в різних формах. Опрацювання опору виступає важливою та необхідною умовою ефективності будь-якого психотерапевтичного процесу, а інтерпретація опору залежить від підходу, в межах якого здійснюється психотерапія.

У психотерапії з дітьми і підлітками психотерапевт зустрічається з неусвідомленим опором не тільки дитини, але і ії батьків (Бремс, Грін, Четік та ін.). У терапевтичній роботі фахівцю доводиться зустрічатися з різними батьківськими реакціями, установками та проекціями. Передусім опір виникає на етапі прийняття батьками рішення звернутися 3 приводу проблем дитини до психолога. Попри зростання популярності психотерапії в суспільстві існують й упередження та стереотипи у ставленні до практики психологічної допомоги. У зв'язку з цим причинами опору можуть виявитися культурні стереотипи, упередження і особистісні особливості батьків. Батькам, які вирішили звернутися до психолога щодо проблем їхніх дітей, доводиться долати не тільки власні сумніви і страхи, але й опір соціального оточення та членів родини, особливо прабатьків. Батьки можуть чинити опір психотерапії, оскільки не хочуть допускати втручання в сімейну систему стороннього елемента, у зв'язку з небажанням виносити інформацію про проблеми дитини за межі сім'ї, страхом розкриттям сімейних таємниць та звернення до інтимних сторін подружніх і дитячо-батьківських стосунків. Досить часто це відбувається у випадках, коли психологічні проблеми чи симптоми дитини слугують стабілізатором сімейної системи, підтримуючи статус-кво дисфункциональної сім'ї (Боуен, Варга, Вітакер та ін.).

Помічено (Хорн, Циантис, Четік та ін.), що батьки, які відчувають у процесі терапії загрозу «втрати» власної дитини або складеного в сім'ї гомеостазу, прояву власних почуттів, що видаються «неадекватними», здебільшого реагують зростанням рівня внутрішньої тривоги та спробами їі відреагування в різних формах, зокрема: ідеалізації/ знецінюванні терапевта; нав'язливістю чи споживацьким ставленням з бажанням перекласти на психолога повноту відповідальності, декларуючи «ми вам привели, а ви зробіть з ним що-небудь...»; намаганнями маніпулювати терапевтом, як власною дитиною; маніпуляціями з дитиною та запереченням щодо іiі труднощів та симптоматики тощо. У випадках, коли замовником терапії виступає школа, медичні установи чи органи опіки, спостерігається зростання тривоги, коли батьки усвідомлено та несвідомо переживають провину й сором, які намагаються витіснити, оскільки «не впоралися» зі своєю батьківською роллю (Четік, 2003, с. 58-65; Циантис, 2006 с. 78-83).

Звернення про допомогу в очах батьків може виглядати як визнання власної некомпетентності та батьківської неспроможності («недостатньо хороше» батьківство) й бути свідченням того, що з ними та їхньою дитиною щось не так. В результаті чого у них загострюються переживання сорому й провини, оскільки не змогли забезпечити власним дітям «нормальний» розвиток, що вражає самооцінку батьків, їх надію і віру у краще майбутнє для їхньої дитини. Багато сучасних матерів несвідомо вважають дитину своїм продовженням («нарцисичним розширенням»), а тому проблеми та певна «недосконалість» дитини переживається ними як власна «неідеальність», що несвідомо загострює їхню нарцисичну вразливість. Батьківське самолюбство може бути уражене і тим, що хтось сторонній (психолог) здатен краще зрозуміти й допомогти дитині, ніж вони самі.

Батьки не завжди схильні підтримувати психотерапію дитини, оскільки звернення до психотерапевта актуалізує несвідомі процеси, пов'язані з їхнім дитячим досвідом взаємодії із 
значущими фігурами. Сучасні дослідження об'єктних стосунків між батьками і дітьми на засадах теорії прив'язаності (Боулбі, Бріш, Ейнсфорт та ін.) засвідчують, що дорослі, у яких в дитинстві виникли порушення прив'язаності, стаючи батьками зберігають цю модель поведінки, що зумовлює появу порушень в їхніх дітей. Водночас у роботі з проблемами i труднощами дитини слід виходити з визнання і поваги до любові й лояльності дітей і батьків до їхньої сімейної системи (Боуен, Варга, Дольто, Сльячефф та ін.). Сучасні дослідники (Бремс, Меллер, Мак-Грат, Педерсон, Сузукі та ін.) наголошують на потребі формування у психологів в епоху глобалізації мультикультурної сенситивності, толерантності та компетентності задля роботи з сім'ями та представниками меншин і субкультур. Усе це вимагає звернення психологів до більш глибокої рефлексії задля особистісної відкритості й мінімізації впливу власних упереджень та стереотипів у терапевтичній взаємодії з дітьми, підлітками та їхніми батьками.

На початку побудови терапевтичних стосунків з сім'ями маленьких та юних пацієнтів психологу доводиться звертатися до стабілізації тривоги їхніх батьків. Передусім батьки потребують емпатійної підтримки психолога в їхньому рішенні щодо звернення про допомогу, у зв'язку 3 їх нарцисичною вразливістю й загостренням тривоги (чи можна довіряти психологу, як буде відбуватися психотерапія, чи достатньо у психолога знань і досвіду, щоб допомогти дитині; скільки буде тривати процес психотерапії тощо); переживаннями провини і сорому, які свідомо і несвідомо відчувають батьки через власну «некомпетентність». Важливо, щоб батьки в ситуації звернення про допомогу відчули підтримку і схвалення психотерапевта, адже звернення про допомогу є сміливим та виваженим кроком, що свідчить про «хороших батьків», які розуміють і люблять свою дитину. Психологу важливо пам'ятати, що переважна більшість батьків любить свою дитину, лише не вміють виражати це адекватно та повною мірою. Також батьки потребують допомоги щодо розуміння вікових особливостей розвитку дітей і підлітків та переживання ними сенситивних і кризових періодів розвитку; з'ясування особливостей побудови стосунків 3 дітьми та підлітками в цей період; обізнаності щодо процесу та результатів терапії. Надійною опорою у побудові терапевтичного альянсу з сім'єю є зосередження уваги на здорових та позитивних аспектах досвіду взаємодії дитини і батьків як головного ресурсу для розвитку та змін у ході терапевтичного процесу.

Практика засвідчує, що інформація, яка надається психологу батьками на первинних інтерв'ю (анамнез та особливості розвитку дитини й впливу на неї соціального середовища та найближчого оточення тощо) є доволі суб'єктивною, а проблема, заявлена батьками чи опікунами, може не відповідати реальній проблемі дитини (Kazdin, Weisz, 1998, c.19-36). Така інформація часто засновується на певному спотвореному сприйняття та інтерпретації поведінки дитини з боку батьків, а також їх спробах приховування й замовчування своїх «провалів» або власних психопатологічних реакцій, а тому завжди слід враховувати ії ймовірну невідповідність реальності. У ході терапевтичної роботи важливим є розуміння ролі сім’ї в розвитку порушень у дитини, а також впливу проблем та порушень у розвитку дитини на ії сім'ю. Дослідники наголошують, що батьки, схильні до спотворення здорових тенденцій дитини та приписування невротичного характеру нормальним потребам розвитку своїх нащадків, припиняють психотерапію, несвідомо вбачаючи у прогресивних змінах загрозу сепарації та розходження з сімейними установками (Karver, Handeslman, 2006, с. 565; Циантис, 2006, с. 93-95). У таких випадках, у зв'язку з несвідомою лояльністю до сімейних установок, маленькі пацієнти відчувають тривогу й прагнуть до відреагування своїх конфліктів протестом та відмовою від проходження терапії. Помічено, що в ситуації проходження терапії в матерів може загострюватися заздрість, ревнощі або ж конкурентні почуття за відданість дитини, оскільки складно «ділитися» своєю дитиною з іншою жінкоютерапевтом, яка видається ідеалізованою або «жахливою» матір'ю (Stefini, Horn, Winkelmann, 2013, c. 192-200).

Подібні ситуації актуалізують у дитячих терапевтів інтенсивні емоційні відгуки (реакції контрперенесення), а тому вимагають особливої уваги й емоційної стійкості. У зв'язку з цим необхідними складовими підготовки дитячого психотерапевта в роботі 3 
дітьми, підлітками та їхніми батьками є розвиток професійної чутливості, усвідомлення та розуміння власних внутрішніх реакцій задля нівелювання їх руйнівного вторгнення в терапевтичний простір.

Ситуація приналежності батьків як обов'язкового елемента дитячої психотерапії створює труднощі в пошуках компромісу в дотриманні етичних принципів професійної діяльності щодо інформування і водночас збереження конфіденційності в роботі 3 дітьми і підлітками. У центрі психотерапевтичного контакту постає потреба захисту конфіденційності дитини-пацієнта, оскільки контракт укладається 3 батьками, на яких покладена відповідальність за дітей i підлітків, а, відтак, вони володіють правом поінформованості про те, що відбувається в ході психотерапії. Однак докладне інформування батьків про зміст терапевтичних сесій, ставить під загрозу конфіденційність й може руйнувати довіру дитини до процесу психотерапії й психотерапевта. У ході терапевтичної роботи у взаємодії зі значущими для дитини дорослими психолог знайомить їх 3 ходом та результатами психотерапії, методами, які використовуються фахівцем, не висвітлюючи змісту окремих сесій.

Висновки і перспективи подальших розвідок. Отже, визнання впливу значимих дорослих на формування особистості дитини зумовлює встановлення в ході терапії тісного робочого альянсу 3 батьками як учасниками психотерапевтичного процесу. Важливою складовою психотерапії з дітьми і підлітками є робота 3 опором батьків, оскільки опір батьків не зникає впродовж усього ходу терапевтичного процесу. Складність терапевтичної роботи з дітьми полягає у знаходженні балансу між дотриманням конфіденційності в роботі 3 дитиною і водночас побудовою продуктивної взаємодії з ії сім'єю. Перспективу подальших досліджень убачаємо в розробці концептуальних засад теорії і практики консультування та психологічного супроводу батьків в терапії з дітьми та підлітками.

\section{СПИСОК ПОСИЛАНЬ}

Бремс, К. (2002). Полное руководство по детской психотерапии. Москва: Эксмо.

Циантис, Дж., Ботиус, С., Холлерфорс, Б. (2006). Работа с родителями: психоаналитическая психотерапія с детьми и подростками. Москва: Когито-Центр.

Четик, М. (2003). Техники детской терапии. Санкт-Петербург: Питер.

Kazdin, A., \& Weisz, J. (1998). Identifying and developing empirically supported child and adolescent treatments. Journal of Consulting and Clinical Psychology, 66, 19-36.

Karver, M. S., Handeslman J. B., Fields S., \& Bickman, L. (2006). Meta-analysis of therapeutic relationship variables in youth and family therapy: The evidence fordifferent relationship variables in the child and adolescent treatment outcome literature. Clinical Psychology Review, 1, 50-65.

Stefini, A., Horn, H., Winkelmann, K., Geiser-Elze, A., Hartmann, M., \& Kronmuller, K. T. (2013). Attachment styles and outcome of psychoanalytic psychotherapy for children and adolescents, 46 (3), 192-200.

\section{REFERENCES}

Brems, K. (2002). Polnoe rukovodstvo po detskoj psihoterapii [Complete guide to child psychotherapy]. Moskva: Eksmo. [in Russian].

Chetik, M. (2003). Tehniki detskoj terapii [Child Therapy Techniques]. Sankt-Peterburg: Piter. [in Russian].

Ciantisa, Dzh., Botius, S., \& Hollerfors, B. (2006). Rabota s roditelyami: psihoanaliticheskaya psihoterapiya s detmi i podrostkami [Work with parents: psychoanalytic psychotherapy with children and adolescents]. Moskva: Kogito-Centr. [in Russian].

Kazdin, A., \& Weisz, J. (1998). Identifying and developing empirically supported child and adolescent treatments. Journal of Consulting and Clinical Psychology, 66, 19-36. [in English].

Karver, M. S., Handeslman, J. B., Fields, S., \& Bickman, L. (2006). Meta-analysis of therapeutic relationship variables in youth and family therapy: The evidence fordifferent relationship 
variables in the child and adolescent treatment outcome literature. Clinical Psychology Review, 1, 50-65. [in English].

Stefini, A., Horn, H., Winkelmann, K., Geiser-Elze, A., Hartmann, M., \& Kronmuller, K. T. (2013). Attachment styles and outcome of psychoanalytic psychotherapy for children and adolescents, 46 (3), 192-200. [in English].

\title{
PSYCHOLOGICAL FEATURES OF WORKING WITH PARENTS IN PSYCHOTHERAPY OF CHILDREN AND ADOLESCENTS
}

Svitlana Lytvynenko

Professor of the Department of Practical Psychology and Psychotherapy ORCID iD: 0000-0002-7736-2152

Vadim Yamnitsky

Professor of the Department of Practical Psychology and Psychotherapy Rivne State University of the Humanities ORCID iD: 0000-0002-1741-1303

DOI https://doi.org/10.35619/prap_rv.vi13.125

\begin{abstract}
The article points out that psychotherapy with children differs from psychotherapy with adults with the more complex structure of the psychotherapeutic situation, which leads to a more complex system of relationships in this situation. Firstly, a child psychotherapist forms dual therapeutic relationships and a working alliance with adults and with a child. Working with parents, the psychologist refers to understanding the features and assessing the possibilities of involving parents to participate in psychotherapy and determine the working style with them. Above all, parents need the empathic support of a psychologist in overcoming resistance to seeking help; as well as assistance in understanding the psychological characteristics and age crises in the development of children and adolescents; understanding the process features and the therapy results. In the course of therapeutic work, it is important to clarify the role of the family in the development of child's disorders, as well as the impact of problems and disorders in the child's development in the family.

It is proved that planning, organizing, and conducting psychotherapy work with children and adolescents, the factors that determine family and parental resistance at the beginning and during the process of psychotherapy should be considered. Neglecting or ignoring child psychotherapists / psychologists to take into account the resistance of the family and the patients'parents may reduce the effectiveness of the therapeutic process and reduce the positive results already achieved, premature termination or interruption of psychotherapy. An important pillar in creating a therapeutic alliance with the family is to focus on the healthy and positive aspects of the child-parent interaction experience as a major resource for development and change during the therapeutic process. It is determined that the situation of parental affiliation as a compulsory element of pediatric psychotherapy makes it difficult to find a compromise in respecting ethical principles of professional activity in informing and at the same time maintaining confidentiality in work with children and adolescents.
\end{abstract}

Keywords: psychotherapy with children and adolescents, parental and family resistance to child and adolescent psychotherapy, therapeutic contract, therapeutic family alliance.

Стаття надійшла 9.11.2019 p. 